\title{
Entomology in South Africa: Where do we come from, where are we now and where are we going?
}

AUTHOR:

Jan H. Giliomee ${ }^{1}$

\section{AFFILIATION:}

${ }^{1}$ Department of Botany and Zoology, Stellenbosch University, Stellenbosch, South Africa

\section{CORRESPONDENCE TO: Jan Giliomee}

EMAIL:

jhg@sun.ac.za

\section{POSTAL ADDRESS:} Department of Botany and Zoology, Stellenbosch University, Matieland 7602, South Africa

\section{KEYWORDS:}

early entomologists; history of entomology; research funding; taxonomy; training

\section{HOW TO CITE:}

Giliomee $\mathrm{JH}$. Entomology in South Africa: Where do we come from, where are we now and where are we going? S Afr J Sci. 2013;109(1/2), Art. \#a004, 3 pages. http://dx.doi.org/10.1590/ sajs.2013/a004

(C) 2013. The Authors.

Published under a Creative Commons Attribution Licence.
Entomology in South Africa can be traced back to the mid-18th century when Ryk Tulbagh was governor at the Cape from 1751 to 1771 . Tulbagh was interested in nature and instructed his gardener, J.A. Auge, to collect plants, insects and other animals for scientists at European universities. He also sent specimens to Linnaeus in Sweden, with whom he as a Dutchman corresponded in Latin, their only common language. To thank and honour him, Linnaeus named for him the plant genus Tulbaghia as well as the beautiful Mountain Pride butterfly Aeropetes tulbaghia L. (Lepidoptera: Satyridae) that occurs along the slopes of Table Mountain.

Linnaeus also described two scale insects from South Africa:Conchaspis capensis (L.) (Hemiptera: Conchaspisdidae) and Ceroplastes myricae (L.) (Hemiptera: Coccidae). They were present on the plants Tulbagh sent to Linnaeus and as a result Linnaeus not only described the plant, but also, in a few lines, the little scale insects he noticed on them.

Some early visitors to the Cape, like Thunberg (in 1770), Sparrmann (1772-1776) and Wahlberg (1836-1845), collected insects for overseas museums and taxonomists, but the first serious entomological studies at the Cape were performed by Roland Trimen (1840-1916) who arrived from London in 1858. ${ }^{1}$ For nearly 20 years, Trimen served the Cape government in various administrative positions before he was appointed as curator of the South African Museum. He had a great interest in Lepidoptera and in his free time produced a catalogue of South African butterflies with descriptions of all the known species at the time, followed by descriptions of new species and studies on the pollination of orchids. During his time as curator he not only published a monumental monograph and various other papers on South African butterflies, but also served on a commission for the eradication of phylloxera.

The next important figure was the Frenchman Louis Péringuey (1855-1924) who arrived at the Cape in 1879 after taking part as a 15-year-old boy in the French-Prussian war. ${ }^{2} \mathrm{He}$ initially taught French, but in his free time worked on the Coleoptera of the South African Museum. After a few years he was appointed by the Museum and, in 1906, became the Director. Péringuey described many new beetles, as well as a few orthopterans and brown lacewings. A number of insects were named after him, the best known being the cocktail ant Crematogaster peringueyi Emery (Hymenoptera: Formicidae). Two devastating plant pests at the time were the Australian bug Icerya purchasi Maskell (Hemiptera: Monophlebidae), introduced in 1873, and phylloxera Dactylosphaera vitifoliae (Fitch) (Hemiptera: Phylloxeridae), which arrived at the Cape during the 1880s. Péringuey was asked to investigate both, although applied entomology was outside his field of expertise.

In 1890, Trimen received a visit from a British friend who worked in the leather tanning industry, but who also had a great interest in entomology - William Distant (1845-1922). Distant liked travelling and had already published a book on the butterflies of Malay. ${ }^{3}$ He paid two extensive visits to the Zuid-Afrikaanse Republiek in 1890-1891 and 1894-1898, during which he collected many insect specimens. These collections resulted in the beautifully illustrated Insecta Transvaaliensia which appeared in 12 sections from 1900 to 1911. Distant paid for this publication himself and wished to publish more sections, but he could not get sponsorship because, as he put it, "the millionaires of the Transvaal have universally shown that they care for none of these things".

During the last 5 years of the 19th century, people trained as entomologists were appointed for the first time in South Africa. They were Charles Lounsbury (1872-1955) and Charles Mally (1872-1951) from the USA and Claude Fuller (1872-1928) from Australia. Interestingly, they were all born within 12 days of one another. Their appointments reflected the need that arose amongst progressive farmers for modern methods of pest control. The taxonomists from the museums were not very helpful in this regard. Péringuey, for example, recommended that grapevines infested with phylloxera be burned and by 1896 over 8 million plants had been destroyed. This approach greatly annoyed the farmers and, in 1893, they petitioned Cecil Rhodes to recruit an applied entomologist. ${ }^{4}$

As a result, in 1895, Lounsbury was appointed as government entomologist at the Cape - the first such position in Africa. He immediately asked for a typewriter and a bicycle, but the government could only afford one of these, so he chose the typewriter. He bought a bicycle with his own funds and conducted many official trips using this vehicle. ${ }^{5}$ In pioneering research he discovered that ticks were vectors of serious animal diseases and worked out a remedy for their control, namely dipping with sodium arsenite, a chemical he also recommended for the control of locusts. He also worked out a spraying programme for fruit trees and persuaded the government to adopt legislation that would prevent the importation of plant material without a permit and make the fumigation of nursery stock with hydrogen cyanide compulsory. He reluctantly participated in what he called the 'ladybird fantasy' of the time (for the control of aphids and scale insects) and, during a holiday in the USA, he collected 17 species of ladybirds which he sent to South Africa. In 1927, he became Head of the Division of Entomology in the Department of Agriculture and moved to Pretoria. He wrote a comprehensive article on the pioneering period of economic entomology in South Africa, ${ }^{6}$ which complemented a paper on the development of entomological science by Janse ${ }^{7}$.

Mally came to South Africa in 1900 and worked as government entomologist in Cape Town, Grahamstown and again at Rosebank, Cape Town before being appointed as a lecturer at the Elsenburg Agricultural College of Stellenbosch University. ${ }^{8}$ He became world famous for developing a bait to control fruit flies and published many papers on the biology and control of local insect pests, including a comprehensive study on maize stalk borer. Stellenbosch University awarded him an honorary doctorate.

Fuller was appointed in 1899 as government entomologist in Natal where he did pioneering work on locust control. In 1910, he was transferred to Pretoria where he focused on termite biology and the tsetse fly problem. 
Together with tsetse, malaria was a major problem and here the great contributions were made by David H.S. Annecke (1895-1955) and Botha de Meillon (1902-2000). De Meillon told me that he one night shared a room with a pig to establish whether Anopheles mosquitoes preferred to feed on him or the pig. In the related field of veterinary entomology, the work of F. Zumpt and G.C. Ullyett was outstanding.

Then there was the great naturalist Sydney Harold ('Stacey') Skaife (1889-1976). At the age of 23 he came from England to join Rondebosch Boys High as a school teacher. While teaching he completed a BSc in Zoology at the South African College. In 1916 he joined the Division of Entomology to work on insect pests of stored food and in 1919 was transferred to Cedara to study the wattle bagworm. In 1921, he returned to the Department of Education and Cape Town as inspector of science. During World War II he was asked to investigate the crashing of several military aircraft at Youngsfield aerodrome. Sabotage was suspected and the mechanic servicing the aircraft was arrested, but, on the millionto-one chance that an insect might be involved, Skaife was consulted. He discovered that leafcutter bees were blocking an essential tube associated with the airspeed indicator with fragments of leaves. ${ }^{9}$ Skaife was a prolific writer and in addition to the monumental African Insect Life (1953) and some 20 other books, he wrote Dwellers in the Darkness (1955) and The Study of Ants (1961), both based largely on his own experiments and observations at his 45-ha smallholding 'Tierbos' in Hout Bay where he kept artificial colonies of various social insects. Few people know that he was also the author of seven detective stories, written in Afrikaans, under the name Hendrik Brand. In 1957, he was awarded an honourary doctorate from the University of Natal. ${ }^{10}$

The early taxonomists had outstanding successors in the likes of C.K. Brain and G. de Lotto (scale insects), G. van Son (butterflies), A.J. Hesse, H.K. Munro and B.R. Stuckenberg (flies), W.G.H. Coaton (termites), D.P. Annecke (parasitic wasps), A.J.T. Janse, E.G.H. Pinhey and L. Vári (moths), J.C. Faure and C. Jacot-Guillarmod (thrips), S. Endrödy-Younga (beetles) and J.G. Theron (leafhoppers). These workers and the many specialists from overseas who described new insect species from South Africa laid the foundations for our knowledge of the insect fauna of South Africa. The taxonomists were complemented at the time by outstanding economic entomologists like E.C.G. Bedford and M.B. Georgala (citrus), A.C. Myburgh and V.B. Whitehead (deciduous fruit and grapevines), S.W. Broodryk (cotton), A. Lea (locusts), G.A. Hepburn and F.G.C. Tooke (forestry), to name a few.

While the monographs and other publications of these taxonomists were mainly used by their peers, books on our insects of more general interest and usefulness to entomologists were Skaife's African Insect Life (1953), revised by John Ledger in 1979, and the very comprehensive Insects in Southern Africa (1985) edited by Clarke H. Scholtz and Erik Holm. For those dealing with economic entomology, there was the early (1929) Insect Pests and their Control in South Africa by C.K. Brain, followed in 1964 by Insects in Southern Africa: How to Control Them by Bernard Smit and in 1982 by Insects and Mites of Cultivated Plants in South Africa by D.P. Annecke and V.C. Moran. If the taxonomic publications were the foundation, these books, together with the prestigious journal African Entomology (established in 1937, together with the Entomological Society, as the Journal of the Entomological Society of Southern Africa), are the building blocks of entomology in South Africa. In this 'building', the decorations aimed at the general public were several butterfly and dragonfly books, Erik Holm's entertaining Inseklopedie (2008) and (with Ansie Dippenaar-Schoeman) Goggo Guide (2010), and the very useful Field Guide to Insects of South Africa (2002) by Mike Picker, Charles Griffiths and Alan Weaving.

Today this 'building' is occupied by the (200 odd) professional entomologists of South Africa. Most were trained at one of the universities that offer an Entomology major (Free State, Natal at Pietermaritzburg, Pretoria, Rhodes, Stellenbosch) or at a university where entomology is being taught as part of a course in Zoology (Cape Town, North West at Potchefstroom, Witwatersrand). In general, they have received very good training from excellent teachers and many have completed or are busy with MSc or PhD studies. However, many lack sufficient knowledge of mathematics and/or statistics which lies at the basis of experimentation and the interpretation of results (as analysed by a computer program). Indications are that sufficient numbers of entomologists are still being trained to fill the vacancies that arise.

Entomologists should be able to identify insects or describe them when new, study the biology and ecology of selected insects and determine how to manage insects that tend to be too abundant (pest control) or too rare (insect conservation). For this purpose, various institutes have been established to serve particular agricultural segments, now coordinated by the Agricultural Research Council (ARC), such as the ones at Nelspruit for tropical and subtropical fruit, Nietvoorbij, Stellenbosch for fruit and vines, Bethlehem for small grains, Potchefstroom for summer grains, Roodeplaat for vegetables and the Plant Protection Research Institute in Pretoria (which also includes the National Collection of Insects and the very active unit working on the biological control of weeds). Some agricultural industries, for example Citrus Research International in Nelspruit and the South Africa Sugarcane Research Institute in Mount Edgecombe, have their own researchers. Medical and veterinary insects are studied at the Malaria Entomology Research Unit, University of the Witwatersrand and the Veterinary Research Institute Onderstepoort, respectively, and toxicity tests on indicator species are conducted by the SA Bureau of Standards. Insects important to forestry are studied at the Forestry and Agricultural Biotechnology Research Institute of the University of Pretoria. The National Research Foundation financially supports university staff and students that do research on insects. Chemical companies that develop, register and sell insecticides employ entomologists to test, register and market them.

From the list of ARC institutes above one might think that our building is solid and that the structures are in place to deal with the insects that cause about $50 \%$ of crop losses despite control measures. And that the agricultural industry, which is responsible for our food security, is well supported by entomological research. However, that is not the case. The structures may be there, but they are not all functioning properly; the building with its solid foundations and strong building blocks is crumbling.

It is well known that agriculture in South Africa faces tremendous problems, such as the uncertainties associated with land restitution, the replacement of experienced farmers with novices that lack the skills and capital required for the complicated, high-tech business that agriculture is today, high input costs and low prices for products, and the inability to compete on international markets with subsidised products when subsidies here are lacking. The lack of subsidies includes the lack of government support for entomological research. At the ARC institutes, research posts are left vacant for long periods and staff that are appointed have to spend much of their time writing proposals for projects to get money from industry, not the state. Senior entomologists that retire are replaced by young and inexperienced people who often are appointed on the basis of criteria other than merit in order to address the imbalances of the past. This situation leads to a huge loss in accumulated knowledge, a reduction in research output and a general decline in morale amongst staff. The Plant Protection Research Institute no longer has its own Director, but shares the position with the Vegetable and Ornamental Plant Institute. If one visits some ARC institutes today, there is no longer a buzz of activity as in the past, but empty offices that indicate degeneration and decay.

Crop producers, realising that research is important to remain competitive and thus farm profitably, now have to channel some of their own funds into research, usually collected by way of levies on products. The money is administered by trusts, established in terms of the Trust Property Control Act (Act no. 57 of 1988), which inherited the assets of the deregulated control boards. They want value for money and are increasingly focusing on the universities rather than the ARC institutes. Thus, the 2011 annual report of Fruitgro Science, which administers the funds of the fruit industry, shows that funding of the ARC has dropped from $69 \%$ of research expenditure to $36 \%$ during the period from $1998 / 1999$ to $2010 / 2011$, while the amount received by Stellenbosch University increased from 20\% to $33 \%$ (Figures 1 and 2). 


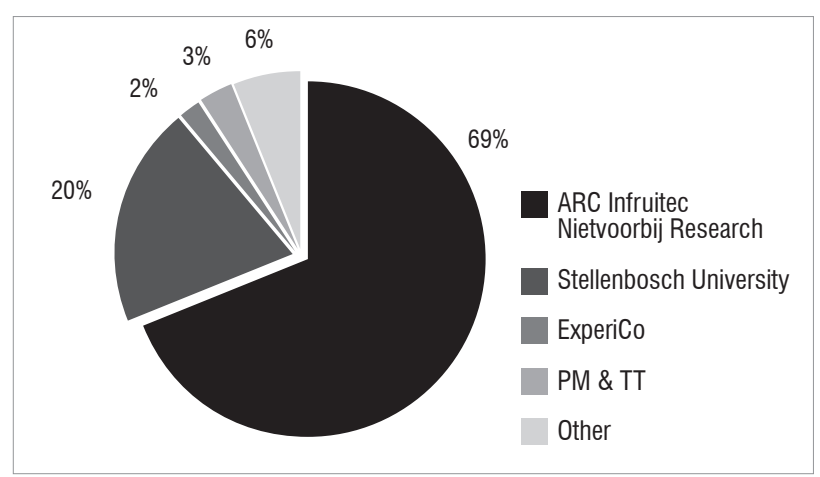

Figure 1: $\quad$ 1998/1999 funding allocation

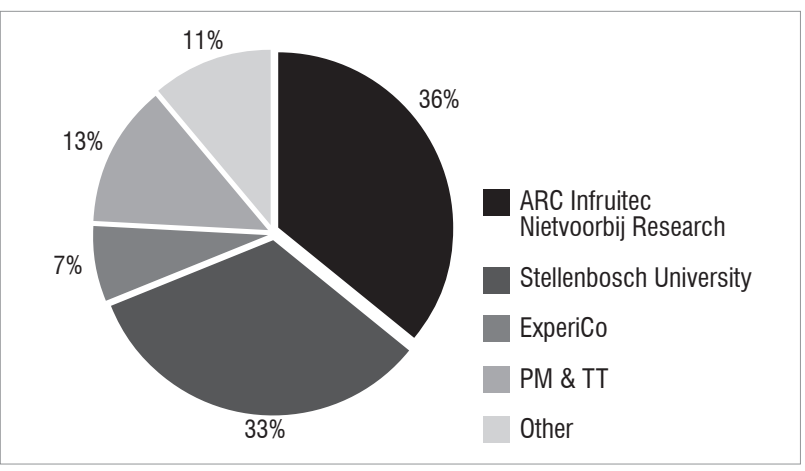

Figure 2: $\quad$ 2010/2011 funding allocation

In 1998/1999, 2\% of the research budget was spent on Stellenbosch University posts; this amount increased to $17 \%$ in $2010 / 2011$. During 2010/2011, Fruitgro Science supported 48 projects at InfruitecNietvoorbij and 39 at Stellenbosch University. The ones supported at the institute are mostly long-term projects such as plant breeding (25 projects), which are not suitable for student research. However, as more Fruitgro Science staff are placed at Stellenbosch University, more long-term projects can be undertaken there. The fruit growers are thus following the foresters in moving entomological research from a government institution to a university.

At some other institutes, such as those conducting research on various grain crops, the current situation may be different as pockets of expertise still exist. However, the general trend in the ARC is a downward spiral in commodity research capacity - at the ARC-Grain Crops Institute the number of entomology posts has dwindled from five to two. Universities like North-West University that position themselves appropriately are increasingly filling the research requirements in this regard.

Research at universities is cheaper because they charge less for the use of infrastructure and no provision has to be made for pensions and medical schemes of student workers. In the shift of research from ARC institutes to universities, South Africa moves closer to the system of land-grant universities in the USA where teaching, research and even extension work are done at universities.

As far as entomology is concerned, state-supported extension work is almost non-existent in South Africa. Farmers have to rely on advice from chemical companies, which are potentially biased towards chemical control. Who is supposed to be selling the idea of integrated pest management to existing and upcoming farmers, to tell them about monitoring, economic thresholds, etc.? The gap between researchers at universities and ARC institutes, and the representatives of chemical companies and big agricultural co-ops needs to be bridged. This bridging is being done very successfully at Stellenbosch University where these groups have been gathering on a regular basis during the fruit season for many years to hear about new research and exchange ideas about fruit and grapevine pest management. Perhaps the Entomological Society has a role to play in this regard.

Chemical pesticides are still the most important tools of pest management. Great strides forward have been made by the chemical industry in developing pesticides that are less toxic to humans and are used in very small quantities. There is very little recognition for these achievements and the onslaught against the products continues. My fear with chemical control is twofold: (1) that the big chemical companies will one day just decide to stop developing pesticides as the profits do not make up for the hassle and costs involved and (2) that insects will develop resistance faster than new groups of pesticides can be discovered. Every new group has taken longer to be discovered than the previous one. Therefore the experience gained with alternative methods of control such as organic farming, biological control, the use of genetically modified crops, sterile insect techniques and mating disruption are useful, but they have very selective applications.

Clearly entomology in South Africa is facing difficult headwinds. The 'building' erected over a century or more is crumbling. The commercial agricultural producers that entomologists serve have declined sharply in number and they have lost much of their political influence. While under the previous dispensation they had the ear of the government, since the regime change in 1994 they are mostly in conflict with the government and its Minister of Agriculture. Agricultural research is now a low priority. Meanwhile the insects are in waiting, or rather are actively evolving, to become better competitors for the available food and more efficient carriers of disease. It seems that only the catastrophe of food shortages and epidemics from insect-borne diseases will open the eyes of the present government to the importance of agricultural research in general, and entomological research in particular.

\section{References}

1. Jacot Guillarmod AFMG. Trimen, Roland. In: De Kock WJ, Krüger DW, editors. Dictionary of South African Biography II. Pretoria: National Council for Social Research, Department of Higher Education; 1972. p. 750-751.

2. Kotze DJ. Péringuey, Louis Albert. In: De Kock WJ, Krüger DW, editors. Dictionary of South African Biography II. Pretoria: National Council for Social Research, Department of Higher Education; 1972. p. 537-539.

3. Giliomee JH. Distant, William Lucas. In: De Kock WJ, Krüger DW, editors. Dictionary of South African Biography II. Pretoria: National Council for Social Research, Department of Higher Education; 1972. p. 198-199.

4. Brown K. Political entomology: The insectile challenge to agricultural development in the Cape colony, 1895-1910. J S Afr Stud. 2003;29:529-549. http://dx.doi.org/10.1080/03057070306203

5. Giliomee JH. Lounsbury, Charles Pugsley. In: Krüger DW, Beyers CJ. Dictionary of South African Biography III. Pretoria: Human Sciences Research Council; 1977. p. 539-540.

6. Lounsbury CP. The pioneer period of economic entomology in South Africa. J Entomol Soc S Afr. 1940;3:9-29.

7. Janse AJT. Glimpses of the development of entomological science in South Africa. J Entomol Soc S Afr. 1940;3:1-8.

8. Giliomee JH. Mally, Charles William. In: Krüger DW, Beyers CJ. Dictionary of South African Biography III. Pretoria: Human Sciences Research Council; 1977. p. 576.

9. Rowan MK. Biography of Dr S.H. Skaife. In: Ledger J. SH Skaife African Insect Life. Cape Town: Struik; 1979. p. 279.

10. Smit B. Skaife, Sydney Harold. In: Krüger DW, Beyers CJ, editors. Dictionary of South African Biography III. Pretoria: Human Sciences Research Council; 1977. p. $711-712$. 